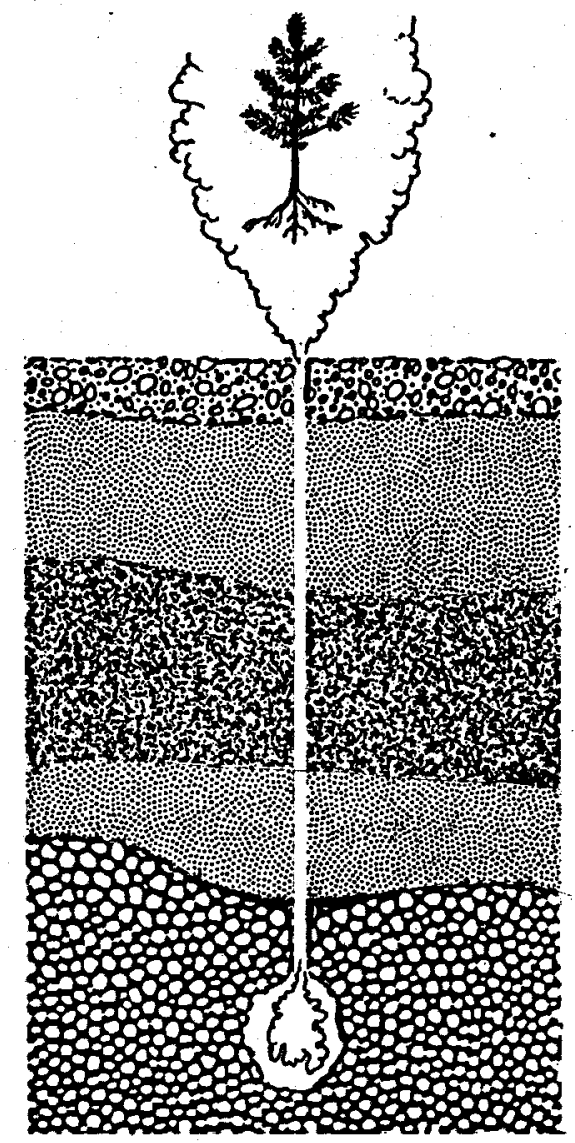
special report

\title{
potential for heating western \\ tree seedling greenhouses with geothermal energy
}

\section{November 1976}
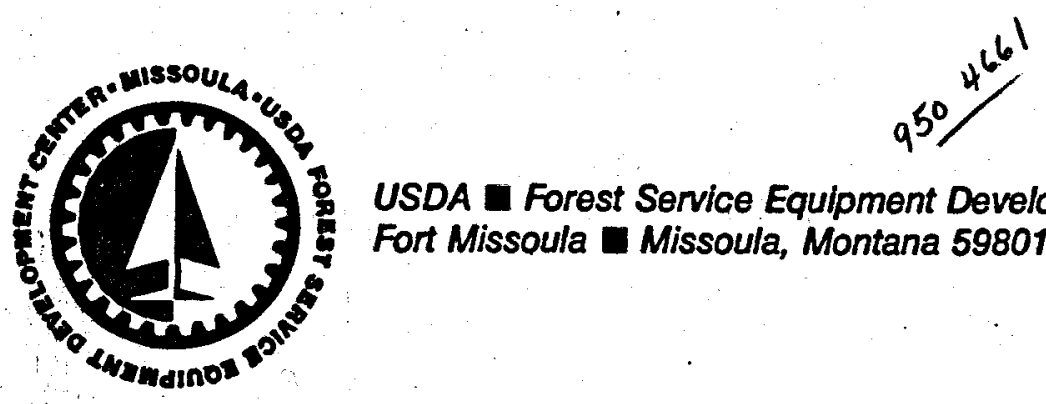

USDA a Forest Service Equipment Development Center

Fort Missoula Missoula, Montana 59801

\section{MASTER}




\section{DISCLAIMER}

This report was prepared as an account of work sponsored by an agency of the United States Government. Neither the United States Government nor any agency Thereof, nor any of their employees, makes any warranty, express or implied, or assumes any legal liability or responsibility for the accuracy, completeness, or usefulness of any information, apparatus, product, or process disclosed, or represents that its use would not infringe privately owned rights. Reference herein to any specific commercial product, process, or service by trade name, trademark, manufacturer, or otherwise does not necessarily constitute or imply its endorsement, recommendation, or favoring by the United States Government or any agency thereof. The views and opinions of authors expressed herein do not necessarily state or reflect those of the United States Government or any agency thereof. 


\section{DISCLAIMER}

Portions of this document may be illegible in electronic image products. Images are produced from the best available original document. 
POTENTIAI FOR HEATING WESTERN TREE SEEDLING GREENHOUSES

WITH GEOTHERMAI ENERGY

By

Stephen E. McDonald, Western Nursery and Greenhouse Specialist, USDA Forest Service, Division of State. and Private Forestry; Lakewood, Colo.

Dr. Carl F. Austin, Supervisory Geologist, Naval. Weapons Center, China Lake, Calif.

James R. Lott, Mechanical Engineer, USDA Forest Service Equipment Development Center, Missoula, Mont.

SPECIAI REPORT

Published by the USDA Forest Service Equipment Development Center, Missoula Mont., and the Division of state and Private Forestry, in cooperation with the Department of the Navy. 
Most U.S. greenhouses are heated with fossil fuels, usually natural gas, which is becoming increasingly expensive. For this reason, the greenhouse industry needs alternative energy sources. One source with high potential is geothermal energy. The technology to apply it to greenhousing is available. Geothermal energy is compatible with greenhouse heat exchange hardware, and it is abundant in the western United States. Geothermal resources suitable for greenhousing are natural springs, deep hot water or steam wells, and waste water from electrical power generating plants.

The wisest approach to using geothermal energy is to seek.out and use known resources. This reduces the risk factors to reliability of the source and its estimated lifespan, questions geologists can make sound predictions about after study.

Factors influencing greenhouse heating needs include climate, elevation, structure, and growing regime, as well as the attributes of the geothermal energy source: heat, quantity, quality. Greenhouse sites should be evaluated for suitability, size, availability of labor supply, markets, etc.

Problems exist in developing any new energy source, but a sound economic assessment based on good engineering and geological advice will illustrate advantages and problems.

When considering geothermal energy as an alternative energy source these steps are recommended: (1) Determine the geographic region greenhouse will serve. (2) Tabulate known geothermal resources within region. (3) Rank potential locations in terms of geothermal fluid chemistry and location. (4) Obtain data on chemistry, flow potential, temperature, and probable lifespan of resources. (5) Conduct economic analysis of proposed greenhouse operation using these geothermal sources; compare with optimum fossil fuel economics and long term availability in the region. (6) Proceed with project if economically attractive. 
CONTENTS

Page

ABSTRACT ........................ . . 11

GREENHOUSES AND ENERGY NEEDS - . . . . . . . . . . . . 1

TYPES OF GEOTHERMAL RESOURCES . . . . . . . . . . . . 4

GEOTHERMAL RESOURCES AND GREENHOUSING . . . . . . . . . 6

EVALUATING THE GEOTHERMAL RESOURCE . . . . . . . . . . 8

EVALUATING THE SITE . - . . . . . . . . . . . . 9

PROBLEMS OF DEVELOPMENT . . . . . . . . . . . . . . 10

CONCLUSIONS . . . . . . . . . . . . . . 12

RECOMMENDATIONS . . . . . . . . . . . . . . . 13

IITERATURE CITED . . . . . . . . . . . . . . 14

TABLE

1. Geothermal Greenhouse Operations . . . . . . . . 3

\section{F IGURES}

1. Thermal springs of the western United States . . . . 5

2. Typical deep geothermal exploration arilling. Rig is drilling to a planned depth of 10,000 feet near

'Phoenix, Ariz. . . . . . . . . . . . . . . 6

3. A "slim" hole wire-line rig exploring for geothermal energy at the Naval Weapons Center Coso geothermal deposit near China Lake, Cal1f. . . ... . . . . : 


\section{GREENHOUSES AND ENERGY NEEDS}

Large-scale growing of tree seedlings in greenhouses for forest planting is relatively new. It is attractive to those engaged in reforestation efforts for several reasons:

- Trees can be grown more reliably since they are not exposed to the vagaries of weather.

- Trees can be grown much faster because growing conditions are optimized (Larson 1975). This allows the forester to respond quicker to reforestation problems.

- Trees are grown in special containers that can lead to faster, higher quality planting jobs. The result in many instances is lower costs per established seedling.

These advantages are not without their price, however. Unlike the traditional bare root stock operation, greenhouse rearing is very energy intensive. Most of this energy is required to heat the greenhouse to maintain optimum growing temperatures (McElroy 1975).

Most greenhouses in the United States are heated with fossil fuels, in most cases natural gas (Duncan 1975), which is becoming increasingly expensive (Eaton 1975). Agricultural uses of natural gas have been assigned low priority compared to domestic heating needs.

It is clear, alternative energy sources for greenhouse heating are needed because of the uncertain supply and price situation of natural gas. Propane and fuel oil are prohibitively expensive in most cases. The environmental impact of burning coal raises serious questions about its potential for widespread heating of greenhouses.

Other nonfossil energy sources are being explored. Some solar-heated greenhouses are operating.
Another energy source with high potential for greenhouse heating is geothermal energy. This is true for several reasons:

- The technology to apply geothermal energy as a greenhouse heat source exists; it is in use at a number of places (Eaton 1975).

- Hot water or steam from geothermal energy sources is compatible with present greenhouse internal heat exchange hardware.

- Usable geothermal energy sources are widely distributed over the western United States (Council for Sci. and Tech. 1972).

- Geothermal energy, once developed, is constantly available and reliable; solar or wind-generated energy is intermittent.

- A great amount of untapped geothermal energy is suitable for greenhouse heating (Council for Sci. and Tech. 1972).

Usually when geothermal energy sources are discussed, three main types are involved:

1. Naturally occurring hot water or steam from springs or geysers.

2. Hot water or steam in wells.

3. Hot water that is the byproduct of a geothermal electrical generating operation. (Obviously, many nongeothermal processes also have waste heat byproducts as well.) We delineate the types of sources now, to alert the reader to possible manmade sources of thermal waste energy applicable to greenhouse operations.

Research and development work is exploring the possibility of pumping water down hot, dry wells and recovering the heated water, but this technique, and others, is still under development and will not be considered further here. 
In addition, this report focuses on the Western States and does not address geopressured fluids of the U.S. gulf coastal areas.

The practice of growing tree seedlings in greenhouses was premised on inexpensive, reliable energy. But if the common source, natural gas, becomes unobtainable or too expensive, the only options left are to abandon greenhouse growing or find another energy source. Geothermal energy, for many reasons, presents a nonfossil fuel alternative for the western United States.

To take advantage of geothermal energy, the greenhouse must be where the energy source is. This reverses the previous practice of bringing the energy to the greenhouse. This fact means rethinking greenhouse site selection, product transportation, and numerous other factors. Greenhouse developers will have to be flexible and opportunistic when selecting their sites. The benefits of an adequate, inexpensive geothermal energy source are twofold: (1) lower longrun unit production costs; (2) lower reforestation costs. Greenhouses continuing to rely on scarce, expensive natural gas probably will be priced out of business.

We hope this report stimulates the forest tree greenhouse industry to begin contemplating alternative energy sources, particularly geothermal energy. We hope to make the reader aware of geothermal's potential for greenhouse heating. In fact, it is heating greenhouses worldwide today (table 1). Most are in the higher latitudes, where seasons are short and climates harsh, but the practice will spread rapidly as fuel costs rise. 
Table 1.--Geothermal greenhouse operations

\begin{tabular}{|c|c|c|c|}
\hline Country & Locality & Comments & References \\
\hline Iceland & Various & $\begin{array}{l}\text { Glass greenhouses heated } \\
\text { by natural steam and hot } \\
\text { water -- one-third } \\
\text { flowers, two-thirds } \\
\text { tomatoes, cucumbers, } \\
\text { lettuce. }\end{array}$ & $\begin{array}{l}\text { Palmason, Zoega } \\
1970 ; \text { Dragone, } \\
\text { Rume 1970. }\end{array}$ \\
\hline USSR & Makhach-Kala & $\begin{array}{l}25,000 \mathrm{sq} \text { meters plus } \\
56,000 \mathrm{sq} \text { meters of green- } \\
\text { house at other localities } \\
\text { producing over } 1 \mathrm{million} \\
\text { tons tomatoes, cucumbers, } \\
\text { and other vegetables per } \\
\text { year. }\end{array}$ & $\begin{array}{l}\text { Khonov, Dvorov } \\
1970 .\end{array}$ \\
\hline Italy & $\begin{array}{l}\text { Castelnuovo } \\
\text { Galzingnano (Padua) }\end{array}$ & $\begin{array}{l}3,000 \mathrm{sq} \text { meters of green- } \\
\text { house. } \\
20,000 \mathrm{sq} \text { meters of green- } \\
\text { house. }\end{array}$ & $\begin{array}{l}\text { Barhier } 1975, \\
\text { Barhier } 1975 .\end{array}$ \\
\hline Hungary & $\begin{array}{l}\text { Szentes and various } \\
\text { localities }\end{array}$ & $\begin{array}{l}800,000 \mathrm{sq} \text { meters of } \\
\text { greenhouse for vegetables: }\end{array}$ & $\begin{array}{l}\text { Boldizsar 1970; } \\
\text { Beltcky n.d. }\end{array}$ \\
\hline Japan & various & $\begin{array}{l}15,528 \mathrm{sq} \text { meters of glass } \\
\text { and plastic greenhouses } \\
\text { for vegetables, fruits, } \\
\text { melons. }\end{array}$ & $\begin{array}{l}\text { Komagata, } \\
\text { Nakamura, } \\
\text { Minokara } 1970 .\end{array}$ \\
\hline USA & Oregon & $\begin{array}{l}26,000 \mathrm{sq} \text { ft of steel- } \\
\text { framed fiberglass green- } \\
\text { houses for tomatoes. }\end{array}$ & Head 1970. \\
\hline New Zeaíána & Various & $\begin{array}{l}\text { Mushrooms, tree seedlings, } \\
\text { tomatoes. }\end{array}$ & $\begin{array}{l}\text { Cooke 1970; } \\
\text { Burrows } 1970 .\end{array}$ \\
\hline Turkey & Kiz1ldere & $\begin{array}{l}\text { Hot water radiator system, } \\
8.8 \times 10^{11} \text { calories per } 6 \\
\text { months. }\end{array}$ & Howard, ed. 1975. \\
\hline
\end{tabular}




\section{TYPES OF GEOTHERMAL RESOURCES}

Geothermal resources suitable for greenhouses are of three types: natural springs or geysers; deep wells with hot water or 'steam; and waste water from geothermal powerplants.

\section{Natural Springs}

A complete listing of thermal springs worldwide is contained in G. A. Waring's Thermal Springs of the United States and other Countries of the World, A summary. If quoting from waring:

strictly defined, any spring or well whose average temperature is noticeably above the mean annual temperature of the air at the same locality may be classed as thermal.

Waring goes on to state:

In the United states only those springs are called thermal whose temperature is at least $15^{\circ} \mathrm{F}$ above the mean annual temperature of the air at their localities.

At present there are over 948 known thermal springs in the 11 Western states, plus some 50 thermal springs in Alaska, excluding those of the Aleutian Islands. Figure 1 shows the general distribution of thermal springs in the western United states.

Many of these springs are too small or too cool for greenhousing, or are used for other activities. On the other hand, such springs often indicate locations where drilling to modest depths could be expected to develop additional hot water resources. Such springs also give details on the characteristics of the geothermal fluids to be found.

- I varing, G. A. 3965 o.8. Gologtcal survey prof Păper 492 , (out of print.)
Examples of the magnitudes of some wellknown springs would be a Nevada spring group flowing some 625 gallons per minute (gpm) at temperatures of $173^{\circ} \mathrm{F}$ to $193^{\circ} \mathrm{F}$ and a California spring with a flow of $825 \mathrm{gpm}$ at $130^{\circ} \mathrm{F}$. Such springs represent major sources of energy. The Nevada spring, for example, could provide 6.25 $x 10^{6}$ Btu per hour with a $20^{\circ} \mathrm{F}$ drop in the water temperature as it passes through the heat exchanger. $27^{\text {. }}$.

\section{Deep Wells}

The second type of geothermal resource is the hot water and steam occurring in deep wells. Drilling to provide hot water for space heating is not new in the United States. Classic examples are Klamath Falls, Oreg., and Reno, Nev. Each of the thermal springs of figure 1 represents a site for potential exploration and development. on the other hand, the exploration for geothermal energy for power, which is rapialy accelerating in the western United states, is resulting in more and more thermal wells that are marginal to uneconomic for generating electrical. power but that have the potential to produce up to thousands of gallons of water per hour at boiling to near bolling temperatures. State bureaus of mines, state regulatory commissions, and the U.S. Geological survey can supply data on such wells.

Even a small test well can produce significant amounts of energy. A 375-foot well drilled by one of the authors in the midsixties produces $30 \mathrm{gpm}$ at $287^{\circ} \mathrm{F}$, for a reasonably recoverable $3 \times 10^{5} \mathrm{Btu}$ per hour, with a $20^{\circ} \mathrm{F}$ drop through the heat exchanger. A number of large wells producing several thousand gpm of bolling water have been drilled in the western United States.

2/. A British Thermal onit is the quantity of heat requlired to raise the temperature of 1 pound of water through I $^{\circ} \mathrm{F}$ (251.98 calorles). This process is reversible. If you drop the temperature of water $1 . \mathrm{F}$ through radiator

(heat exchanger), you extract 1 Btu. 


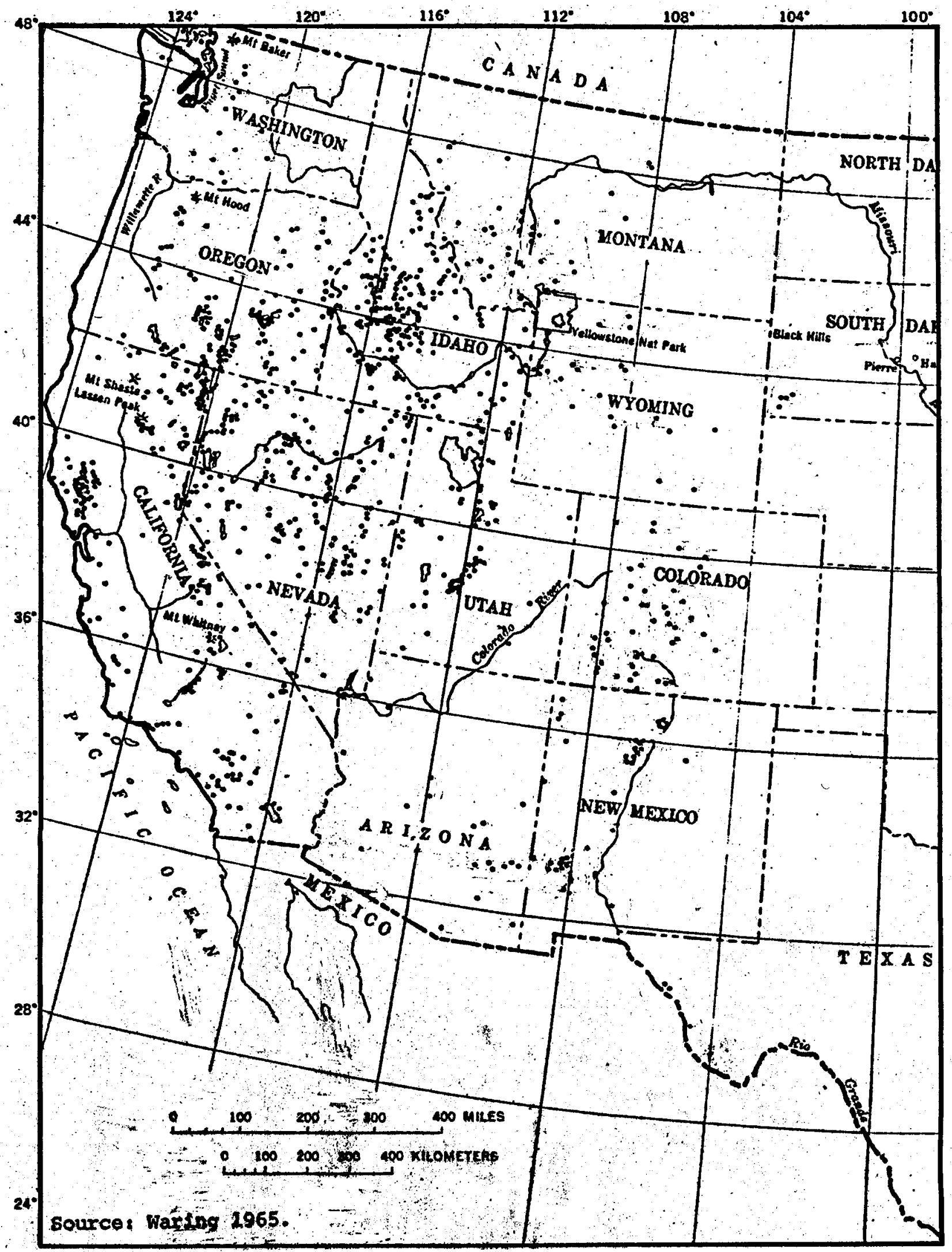

Figure 1.--Thermal springs of the western United States. 


\section{Waste Water}

The third resource of definite interest is the waste water from an operating geothermal. powerplant. At a plant where a geothermal fluid is allowed to flash to steam, the portion not flashing is an obvious hot water resource with massive amounts of energy. One of the

megawatt geothermal plant (the Cerro Prieto plant near Mexicali, Mexico) where the residual water after flashing to steam is blown into the atmosphere and represents 80 percent of the produced fluids or $3,139,950$ pounds per hour of water at $320^{\circ} \mathrm{F}$ (Commission Federal De Electricidad n.d.). This represents $3.77 \times 10^{8}$ Btu per hour with a $120^{\circ} \mathrm{F}$ drop. Such quantities of energy--though not conventionally recoverable as electricity--still could operate extensive greenhouse facilities.

\section{GEOTHERMAL RESOURCES AND GREENHOUSING}

There are three basic approaches to developing geothermal energy for greenhousing:

One approach is to select the greenhouse site on nongeothermal criteria and then attempt to explore for. geothermal energy in the vicinity. The anticipated success rate for this approach is near zero.

The second approach is to explore for new geothermal energy, and when it is found, build the greenhouse. This approach is successful but expensive (Austin, Austin, and Leonard 1971). All the risk factors inherent in mineral exploration are present. Success would be no better than for wildcaters in the oil business, if that good, as the geothermal industry is new, with still much to learn. Obviously, some prospects are less risky than others. By using demonstrable geological controls while relying on "step-out situations," that is exploring adjacent to known thermal deposits and hot water wells or hot springs systems, the risks can be reduced. In all cases,

the exploration must be completed and the resource proven before beginning final plans for a greenhouse system.

Shallow drilling (under 500 feet) next to hot springs or fumarole areas can be done with conventional water well or mineral exploration equipment for $\$ 10$ to $\$ 20$ a foot, plus the costs of safety equipment required by regulation during the drilling operation itself--such as blowout preventer stacks.

Deep drilling to depths ranging from 500 feet to 10,000 feet or more requires increasingly massive, expensive equipment. Figure 2 shows a typical deep geothermal exploration well using oil field technology. Costs of $\$ 1$ million per well or more are not unusual. Research and development is underway to prove out "slim" hole drilling techniques enabling faster, less expensive drilling for exploration and, in some cases, limited production.

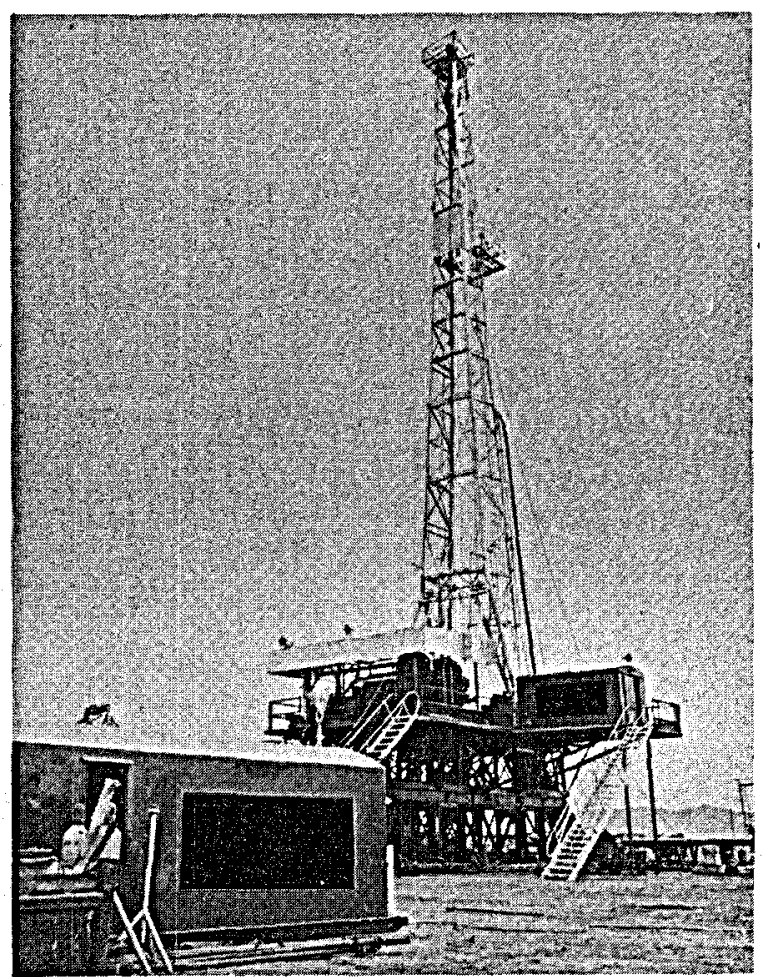

Figure 2.--Typical deep geothermal exploration drilling. Rig is drilling to a planned depth of 10,000 feet near Phoenix, Ariz. 


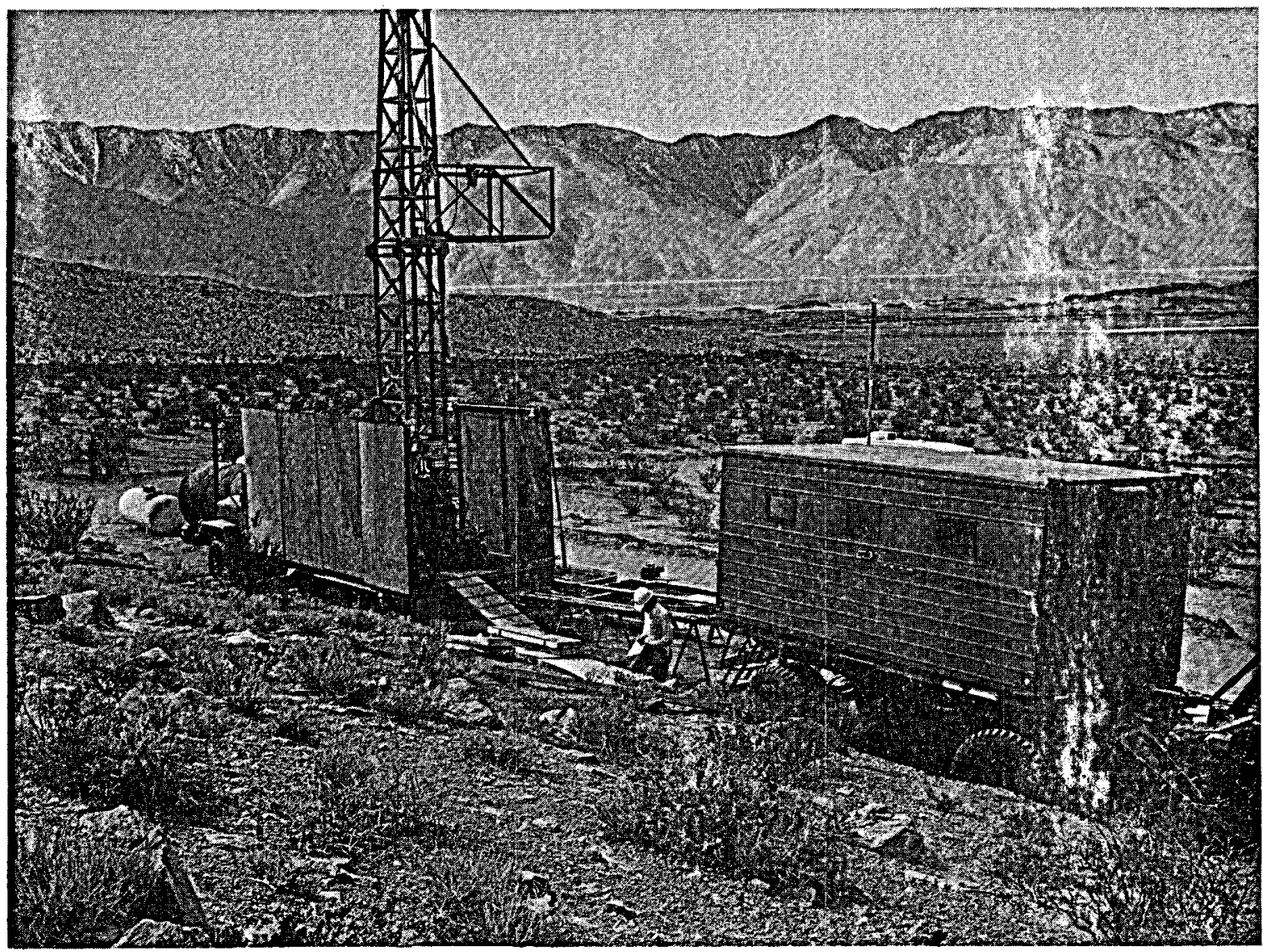

Figure 3.--A "slim" hole wire-line rig exploring for geothermal energy at the Naval Weapons Center Coso geothermal deposit near China Lake, Calif.

Figure 3 shows a "slim" hole wireline rig with a 5,000-foot capability operating at the Naval Weapons Center Coso geothermal deposit. If this type of drilling proves successful, exploration costs may be sharply reduced in the next year or two.

When drilling near natural springs, the driller is faced with legal-environmental considerations.

Well drilling in the vicinity of a natural hot springs often can lead to a legal aispute if the hot springs flow should decrease, whether or not the drilling was responsible. In addition, a rapidly increasing body of law and regulation pertaining to drilling into hot springs or other thermal resource must be complied with.
Nearly all natural hot springs of any significant size are privately owned, and diverting the hot waters of a popular picnic site or spa for greenhouse use will require careful public relations efforts. With respect to western hot springs, per se, virtually all have served as campsites, leading to environmental impact difficulties if the spring area is commercialiy undeveloped prior to greenhouse development.

The third approach is to seek out and use proven hot water resources--natural springs, existing wells, or waste water from powerplants. This is the most practical approach for the greenhouse industry today. It avoids the risks of exploration and enables the greenhouse industry to concentrate on resource use in an area where it already has expertise. 
Existing geothermal resources are:

- Hot springs with large surface flows at high temperatures. Here the waters emerging at the surface are. collected and piped into the greenhouse, and the cooled water can be returned to the spring owner for further use. Environmental concerns and problems are minimal.

- Welis with hot water or steam production. Historically, a great many shallow wells have been drilled in and around hot springs and fumarole locations. These wells produce temperatures and pressures too low for electric power generation, but they offer an attractive, relatively proven resource for heating greenhouses. Such old wells may need repairs, but they avoid the costs and risks of exploration. In addition, the greenhouse industry should monitor geothermal power exploration in the western United states. Such exploration will find far more hot water sources than the water/steam sources suitable for electric power. In other words, an "unproductive". hole for electric power generation may be Ideal for greenhouse heating. As examples, recent deep drillings in Nevada, Arizona, Montana, California, and Utah have developed hot water without electric power production potential with today's technology. Yet from an energy standpoint, this hot water could support extensive greenhousing.

- Waste water from powerplants. An excelient example of the potential for waste water heat production is the Cerro Prieto geothermal plant near Mexicali, Mexico. The United States has one large geothermal powerplant complex, located near cloverdale, Calif. (the Big Geysers). This complex produces significant quantities of hot waste water that is reinjected into the ground.

Facilities between well and greenhouse depend largely on the chemistry of the fluid produced. If heat alone' is the product, then a closed loop that transfers fluid from the naturally flowing well or deep well pump to the greenhouse and then from the greenhouse to a disposal field or reinjection well is all that is needed. The resulting heat may be used to warm the greenhouse through heat exchangers or may be used to heat the seedbed (Boersma and Rykbost 1975). If contained gases such as $\mathrm{CO}_{2}$ are to be produced for use in the greenhouse, then separation equipment may be inserted in the loop. If the fluid is for warm water irrigation, it may be of usable quality as produced, may be flashed to steam and then condensed, or may require fairly extensive chemical treatment. This depends on the chemistry of the geothermal source.

\section{EVALUATING THE GEOTHERMAL RESOURCE}

Once the resource is located it must be evaluated to determine if it can properly heat the greenhouse. The answer depends on greenhouse heating needs and the attributes of the energy source.

Factors influencing greenhouse heat requirements include:

Climate. The colder and darker the climate where the greenhouse is placed, the higher its demand for energy to maintain a given growing regime.

Elevation. High elevation sites are not only colder than lower elevation sites at the same latitude but also have less dense air so combustion equipment is less effective.

Structure. Different greenhouse structures lose heat at different rates due to differing insulative factors.

Growing Regime. Growing regimes that require high temperatures, low humidities (high air exchange rates), or both require more energy input.

Because of variables in these factors, the heating requirements must be calculated for each greenhouse. The necessary formulas and physical data are available in the greenhouse industry, where they are used to calculate heating and cooling needs of each new greenhouse (Augsburger, Bohanon, and Calhoun 1970). The point being made here is that a given figure of heat requirements per square foot of 
greenhouse volume cannot be defined (without specifics). Location, structure, and growing regime can provide an approximation of "peak" requirements, however, and any equipment necessary to use a geothermal energy source can be sized accordingly .

The attributes of the geothermal energy source bear directly on the potential for greenhouse heating. These attributes can be categorized as:

Heat. How hot is the water? The available heat in hot.water is determined by how much its temperature drops as it passes through the heat exchanger. Pexhaps it is low-pressure steam, which is better still, Generally, the hotter the source the less hardware (smaller heat exchanger) required to warm the air in the greenhouse and the smaller the volume of hot water or steam to be moved from source to greenhouse (Council for Sci. and Tech. 1972). One can conclude that the hotter the fluid, the less the capital investment. Hence, a small but hot geothermal energy source may well be more attractive than a large, low-temperature one. On the other hand, if the source produces water at moderate temperatures, more can be moved through larger heat exchangers in the greenhouse. And finally, if the water produced is not hot enough, it can be heated in a boiler, perhaps still with a sizable fuel savings.

Quantity. How much steam or hot water is available? If the volume is insufficient to heat the greenhouse, it can be supplemented. But, generally, only sites with enough geothermal energy for projected needs should be developed.

Quality. What is the chemical makeup of the water from the source? If it is so corrosive that it rapidly destroys pipes or causes extensive scaling, it may be unusable. An example of this is the hot brines of very high salinity. produced by wells at the Salton Sea in California. These brines--some are undergoing extensive heat exchanger testing--have dissolved solids of up to 334,987 parts per million (ppm) (Austin 1964).

If the water introduces large quantities of sulphide gases into the atmosphere, it may be unsuitable for growing seedlings. If it contains less than 1,500 ppm total dissolved solids, no heavy metals, and very little sulphide or boron, it can be used for warm water irrigation with beneficial results.

Typical geothermal waters do contain significant quantities of carbon dioxide $\left(\mathrm{CO}_{2}\right)$, hydrogen sulfide $\left(\mathrm{H}_{2} \mathrm{~S}\right)$, boron, and related volcanic gases. Whether or not these are present in harmful quantities depends on the geologic setting and the degree of groundwater dilution (Austin 1966). Most geothermal steams contain considerable $\mathrm{CO}_{2}$. (For example, at the Naval Weapons Cênter Coso geothermal near China Lake, Calif., 98 percent of the material produced other than water vapor is $\mathrm{CO}_{2}$ (Ross and Yates 1943).)

We should point out that while deleterious gases in the water may prevent its use for warm water irrigation, it can still be a heat source, as long as the objectionable components can be disposed of suitably.

\section{EVALUATING THE SITE}

While the geothermal resource is being evaluated, the proposed greenhouse site must also undergo scrutiny. Considerations should include:

Site Availability. If the site is suitable for greenhouse plans is it available? Purchase may not be, required if a lease can be arranged. Are water rights available? As of this writing, a legal controversy exists over geothermal energy: Is it groundwater or is it mineral in character? Where the spring owner or landowner owns both water and mineral rights, the question can be avoided. In the case of shallow thermal wells or springs on lands where the mineral rights are

\footnotetext{
33/Tinus, R. N. i and s. E. NeDonala (n.d,) Contalnerized tree seedling growing manual. - Unpublished report. 0.s. Dept. Agric. For. serv:
} 
reserved to the government and the water rights to the landowner, this question, which is now in the courts, should be/ settled before development planning. 4/ Is there a suitable site to locate all of the installation? Is it large enough? Flat enough? Does access exist?

Location. The distance from the proposed greenhouse to tree seedling planting sites is of some importance. Transportation costs are a major factor in the delivered price of "containerized" tree seedlings because - they are bulky. But some added costs can be tolerated in the interest of acquiring inexpensive energy.

The distance of the site from a labor supply, maintenance services, and supplies also should influence the site choice. Again, a cheap energy source may be worth such higher costs.

Political Considerations. They are always part of project development. Greenhouse planning is no exception. Geothermal energy development can be a nonpolluting industry if the waste hot water is disposed of properly. Reforestation is well supported by the public. Cooperating electrical generating facilities can acquire much goodwill by providing energy to grow trees for new forests.

\section{PROBLEMS OF DEVELOPMENT}

Problems exist in developing any energy source. Often the problems are hidden from us as consumers because they are problems of finding and tapping the resource--developer problems. We become aware of them belatedly when prices go up or availability drops. Natural gas is a good example.

When contemplating development of a geothermal energy source for greenhouse operations, the nurseryman as consumer and developer must confront any problems from the beginning. These can range from simple to extremely complex and difficult. At one extreme, tapping the excess hot water from an electrical generating facility or large natural hot spring may be easy and direct, with the only problems access, water rights, and lease or purchase of the site. At the other extreme, the discovery and development of a geothermal deep well may be bassed on judgment and prediction and require large expenditures of capital and $a$ high degree of risk before the result is known.

The problems often appear difficult to overcome when compared with simply buying fuel from a commercial energy dealer. But an economic evaluation of the benefits in each case often bears out the wisdom of geothermal energy development, especially in view of the uncertain price and availability regarding other energy sources.

In any human endeavor, the amount of risk assumed is usually proportionate to the stakes of the "game." Most geothermal development for greenhouse heat sources should rely on nearly "sure things" because the stakes in greenhouse energy projects are relatively low. Fortunately it appears there are numerous opportunities for greenhouse-related geothermal development in the western United States that are almost risk-free thanks to the fact that greenhouses can operate with lowergrade heat sources than electrical generating plants. This is an advantage the industry should act on.

If greenhouse developers attempt to use known geothermal heat sources; it reduces the risk factors to two: (1) the rellability of the source, and (2) its estimated lifespan.

Usually, after Initial measurements and study of naturally occurring geothermal sources, geologists can make sound predictions of the reliability and lifespan

4 U.S. Govermment (appeliant) vs Union oil co. of calif., et. al. (appellees), 74-1574. on appeal from the U.S. District Court for the Northern District of California. Geothermal Kinetics, Inc. (plaintiff) vs Union Oil Co. of California (defendent), 75314. Declsion for plaintiff to the effect geothermal fluld is a thermal comodity 
of geothermal sources. Such predictions take much of the risk out of development ventures.

Predictability and reliability are really strong advantages arguing for geothermal development. No one will turn this energy source off or fail to deliver it on time. It will be available 24 hours a day, 7 days a week, year after year, once it is assessed and developed properly.

An economic assessment of projected costs of geothermal development for greenhouse heating is essential. Such evaluations can be short term or long term, depending on the length of view of the developer, arrangements for acquiring the source, the scale of the prospective greenhouse operation, and so forth.

The developer must walk a fine line. He should not plow development costs into a geothermal site that cannot reasonably be recovered; on the other hand, he has to expend enough capital for development to provide a technically sound operation within the overall capital expenditure constraints set in the preliminary evaluation of the site and its development. As a rule of thumb, the more hot water to be used, the more can be spent developing the greenhouse complex.

The message is just this: Enter geothermal development projects objectively, not as an escape from real-world energy prices or as an infatuation with alternative enefgy sources. Such realism will guide you around many of the economic pitfalls in geothermal development.

Another benefit of the objective economic evaluation is the fact that it builds confldence in the proposed development. In effect, the analysis declares whether it is a rational move. Greenhouse developers who must deal with an administrative hierarchy will find this of value. Administrators tend to be conservative because they are the ones assessing risks and alternatives for the company or agency. Geothermal energy development is "catchy" and attractive because it carries an aura of progressiveness, but it is also new and somewhat mysterious to most people. A sound economic evaluation based on good engineering and geological advice will illustrate the advantages and problems. This minimizes the "unknowns" so managers can then make decisions based on the best data possible.

And finally, it is well to note that once developed, geothermal energy costs are a more or less fixed part of the product price. So one of the variables most difficult to estimate when prices of the greenhouse products are set becomes, largely, a "known" entity. This provides a competitive advantage to greenhouse operators with geothermal heat over those with conventional sources.

Environmental considerations must be a part of any development. Geothermal development, like any other, should not upset the ecosystem that the project will be a part of. Compared to other energy developments, geothermal development has less potential impact: No combustive byproducts are generated to foul air or water. There may be chemical or gaseous byproducts typical of volcanic emissions, but with careful design and operation, geothermal pollutants are minimal or nonexistent. Pollution-free operation is far more easily achieved in greenhousing than geothermal electrical power production because the greenhouse does not require open systems with cooling towers and the like. If environmental considerations dictate, the fluid need never be exposed to the atmosphere. It can be produced, run through the heat exchanger, and reinjected, all as a closed system.

However, a number of characteristics about geothermal development can be environmentally damaging. These can be itemized as:

Surplus Hot Water. Disposing of surplus hot water can be a serious problem. Thermal pollution of streams and lakes can harm aquatic plants and animals. Ideally, surplus warm water could irrigate agricultural land or be reinjected into the ground.

Visual Impact. Surface piping, steam from wellheads and separators or cooling 
ponds, and even the greenhouses themselves can be eyesores to some people. This should be considered in site and landscaping plans.

Development Impact. As mentioned earlier, geothermal energy for direct use is where you find it. Accordingly, greenhouses heated with geothermal energy often will be located at sites that are illogical in terms of present thinking. Patterns of thought about transport economics, administration, and access will have to be amended in many instances. Project development will occur at times in what appear to be unusual places. Pristine sites may be developed, or the greenhouse may be put in the parking lot of a generating facility. Such locations will stir controversy because of apparent incongruity with past practice. Efforts will be required to educate and inform people about what is happening and why, to avoid controversy.

In the final analysis, those who have developed geothermally heated greenhouses will be on environmentally sound footing compared to developers converting from gas and ofl to coal.

Corrosion and Scaling. These can be major problems. The water from geothermal springs and wells can vary from culinaryquality water to water containing high levels of sulphides, chlorides, borates, carbonates, heavy metals, etc., that make it unusable. The geothermal resource in the United states has been exploited very little (Muffler 1973). Greenhouse developers should seek only geothermal sources having excellent quality.

Hot springs can deposit many different materials. The most common are those that provide:

- Waters that deposit carbonates and iron compounds.

- Waters that deposit silicon.

- Waters that contain sulphide ions and, quite often, chlorides, heavy metals, and borates. When exposed to oxygen from the air, water from the latter rapidly turns highly acidic and also yields acidic mists and fumes. Corrosion becomes a major problem once the water is exposed to the air, but the water may be usable in a closed system. Such water is usually quite acid in nature if taken from shallow wells, but may not be acid at deeper leve1s. As an example, the near-surface steam at the Naval Weapons Center coso geothermal has a pH of 6.4; yet the $\mathrm{pH} 375$ feet deeper is 9.0. Springs 2 miles west have a surface $\mathrm{pH}$ of 1.5. (Austin, Austin, and Leonard 1971.)

Most deeper geothermal fluids can cause scaling in pipes and heat exchangers. Large temperature drops in heat exchangers, especially with concentrated brines, can prove disastrous. Heat exchange technology for dense geothermal brines is undergoing extensive study, especially. for the Imperial Valley/salton Sea brines.

In any case, the greenhouse developer should "zero in" on only the best geothermal prospects, then have the water chemically analyzed and evaluated for impact on greenhouse hardware design and maintenance. Skilled professional help should be employed in this chemical evaluation. Little or no capital should be expended until experts have evaluated the quality, quantity, reliability, and IIfespan of the source.

Corrosion can be an important consideration when placing greenhouses near a geothermal steam operated generating plant. The hot water from the plant may be of high quality for greenhouse use because of the quasidistillation process it has gone through in the plant. However, enough noncondensable gases may stili be present to put sulphides into the air at the cooling towers at geothermal plants. Acidic water vapor drifting into and onto the greenhouses can harm the greenhouse and the plants in 1t. "The acidity of the tower output should be checked, and the greenhouses should be upwind from the towers in such instances.

\section{CONCLUSIONS}

The greenhouse industry is in a unique position. Other than limited use for resort and spa purposes, little market exists today for geothermal energy that is too low grade for direct electrical energy production. This means the greenhouse industry has an opportunity to choose optimal geothermal power sources from among the many known deposits. 
1. Determine the broad geographic region the greenhouse will serve.

2. Tabulate the known geothermal resources within that region. For known springs use Waring's Thermal Springs of the United States and Other Countries of the World, A sumary and other U.S. Geological Survey materials; for listings of wells with potential for hot water or steam productions draw on State geological surveys, state regulatory commissions, and the Conservation Division of the U.S. Geological Survey.

3. Rank these potential locations in terms of geothermal fluid chemistry and location, to provide a list of candidate sites in the order they are to be examined in detail.

4. Obtain data on chemistry, flow potential, temperature, and probable lifespan through owners, geological service agencies, and consultants.

5. Conduct an economic analysis of the proposed greenhouse operation using these known geothermal sources, compare with the optimum fossil fuel economics and long term availability in the same region.

6. Proceed with project if economically attractive.

Geothermal fluids have the capability of providing a continuing, dependable energy source suitable for greenhouse operation. This resource is not a panacea, but its careful evaluation and use can provide greenhouse operations with significant cost savings while avoiding the uncertaintles associated with fossil fuels. 


\section{ITTERATURE CITED}

Augsburger, N. D., H. R. Bohanon, and J. I. Calhoun.

1970. The greenhouse climate control handbook. Acme Engineering and Manufacturing Corp.

Austin, C. F., W. H. Austin, Jr., and G. W. Leonard.

1971. Geothermal science and technology--a national program. U.S. Dept. of Navy, Naval Weapons Ctr... TS 45-029-72. (Reprinted in serial 92-31, U.S. Gov't. Printing office, Washington; D.C. 1972.)

Austin, C. $F$.

1966. Selection criteria for geothermal prospects. Rept. 13, part C, Nevada Bureau of Mines.

Austin, C. F.

1964. Coso hot springs--a geologic challenge. U.S. Dept. of Navy, Naval Weapons Ctr., Ts 64-180, June.

Barhier, E.

1975. Italian national research council. quoted in Present status and future prospects for nonelectrical uses of geothermal resources. J. H. Howard, ed. Lawrence Iivermore Iaboratory, UCRI 51926, 15 oct.

Beltcky. I.

(n.a.) Development and utilization of thermal waters in Hungary. Geothermics, $1,3,972$, p. 103-112.

Boersma, I., and K. A. Rykbost.

1975. Soil warming with powerplant waste heat in greenhouses. Hort. Sci., 10, p. 28-30.

Boldizsar, T.

1970. Geothermal energy production from porous sediments in Hungary. In United Nations symposium on the development and utilization of geothermal resources, Pisa. Geothermics, special issue 2, vol. 2, part 1. p. 99-109.
Burrows, W.

1970. Geothermal energy resources for heating and associated applications in Rotorua and surrounding areas. In United Nations symposium on the development and utilization of geothermal resources, Pisa. Geothermics, special issue 2, vol. 2, part 2, p. 1662-1669.

Commission Federal De Electricidad.

(n.d.) Cerro Prieto geothermal plant. Divison Baja, California.

Cooke, W. I.

1970. Some methods of dealing with low enthalpy water in the Rotorua area of New zealand. In United Nations symposium on the development and utilization of geothermal resources, Pisa. Geothermics, special issue 2, vol. 2, part 2, p. 1600-1675.

Council of Science and Technology.

1972. Assessment of geothermal resources--panel on geothermal energy research. $100 \mathrm{p}$.

1972. Handbook of fundamentals. American Society of Heating, Refrigerating and Air-Conditioning Engineers.

Dragone, G., and O. Rume.

1970. Pilot greenhouse for the ut11ization of low temperature waters. In United Nations symposium on the development and utilization of geothermal resources, Pisa. Geothermics, special issue 2, vol. 2, part 1. p. 918-920.

Duncan, G.

1975. Greenhouse site selection. In Tenn. Valley Auth. greenhouse vegetable workshop. Tenn. Valley Auth. Bu11. Y-94, p. 44-48.

Eaton, W.

1975. Geothermal energy. U.S. Energy Res. and Devel. Admin., Washington, D.C., 42 p. 
Head, J.

1970. Goethermal energy for greenhouse heating. Ore Bin, 32 (9): 182-183.

Howard, J. H., ed.

1975. Present status and future prospects for nonelectrical uses of geothermal resources. Lawrence Livermore Laboratory, UCRL 51926, 15 Oct.

Khonov, A. N. T., and I. M. Dvorov.

1970. Development of research and utilization of geothermal resources in the USSR. In United Nations symposium on the development and utilization of geothermal resources, Pisa. Geothermics, special issue 2, vol. 2, p. 1072-1078.

Komagata. S., H. Nakamuxa, and Y. Minokara. 1970. The status of geothermal utilization in Japan. In United Nations symposium on the development and utilization of geothermal resources, Pisa. Geothermics, special issue 2, vol. 2, part 1, p. 185-196.

Larson, P.

1975. The upper limit of seedling growth. In Proceedings of the North American Containerized Forest Tree seedling Symposium. Great Plains Agricultural Council Pub. 68, p. 62-76.
McElroy, $R$.

. 1975. The competitive position of greenhouse vegetables: a study of rising fuel costs. In Tenn. Valley Auth. greenhouse vegetable workshop. Tenn. Valley Auth. Bull. Y-94, P. 63-66.

Muffler, L. J. P.

1973. Geothermal resources. U.S. Geological Survey Prof. Paper 820, 722 p.

Palmason, G. , and J. Zoega.

1970. Geothermal energy development in Iceland, 1960-69. In United Nations symposium on the development and utilization of geothermal resources, Pisa. Geothermics, special 1ssue 2, vol. 2, part 1, p. 73-76.

Ross, Clyde P., and Robert G. Yates. 1943. The Coso quicksilver district, Inyo County, California. U.S. Geological Survey Bull. 936-Q, p. 395-416. 